\title{
Disclosing Islamic Values and Cultures via Museums in Tourism Industry
}

\author{
AHMAD YUNUS MOHD NOOR* \& NAJWA AMALINA ABDUL WAHAB ${ }^{1}$
}

\begin{abstract}
Islamic values and cultures can be easily seen through its believers. It is due to the normal human behavior that will make an expectation when seeing somebody's attitude spontaneously. In tourism industry, museums are the most important things to introduce or to expose local cultures and values especially in Melaka as a World Historical Heritage. Hence, this study aims to investigate how the museums in Central Melaka attempt to sustain Islamic values, to observe on how the museums approach in exposing Islamic values towards the tourist and to investigate the tourist awareness on museums activities during their visit. The study used a qualitative method which data is collected by interviewing Muslim and non-Muslim tourists as well as person incharge of the museums. Five museums have been selected for this study due to the opportunities on exposing and introducing Islamic values to the tourist. The results show that museums do have the ability to show Islamic values and cultures. One of the informants express that Melaka has its own uniqueness which could not be found in any other places. This study has been done to gather sources as a preparation for research entitled 'Influence of Tourism towards Sustainability of Islamic Values'.
\end{abstract}

Keywords: Islamic values, Islamic cultures, museum, religiotourism, tourism

Melaka is a state in south area of Peninsular Malaysia. It is located between Negeri Sembilan and Johor. In 2008, UNESCO has announced Melaka as World Heritage City (Ruziah et al. 2014). Melaka provided a tourism activities based on 'Historical Heritage and Malaysian Community Cultures' as tourism theme. With the slogan 'Visiting Melaka Means Visiting Malaysia' has brought more tourist to Melaka. Melaka is also known as Indonesian tourist gateway (Hamzah et al. 2011). The role of a tourism gateway clearly provide the possibility for the direct movements of tourist and purposes of this segment. The most important thing is that the flow of exchanges of import and export provided the opportunity of widening the strategic network between entrepreneurs and benefited tourist from both sides.

As other states in Malaysia, Melaka has an organization or party which organize and develop museums in this state for tourism purposes. It is called Perbadanan Muzium Melaka or PERZIM. It is corporate body to develop museum artifacts in the context of educational development and tourism. Until this paper written, it has organizing 26 museums including Naning Museum that has recently open for the public since May 2017, 11 galleries and several historical sites in the entire Melaka. As a state located in the country that has granted Islam as a formal

\footnotetext{
${ }^{1}$ Ahmad Yunus bin Mohd Noor*(Corresponding author), Ph.D., senior lecturer at Department of Theology and Philosophy, Faculty of Islamic Studies, Universiti Kebangsaan Malaysia, 43600 BANGI, Selangor, Malaysia, email: a_yunus@ukm.edu.my; Najwa Amalina binti Abdul Wahab, M.A. candidate at Department of Theology and Philosophy, Faculty of Islamic Studies, Universiti Kebangsaan Malaysia, 43600 BANGI, Selangor, Malaysia, email: p90010@siswa.ukm.edu.my.
}

https://doi.org/10.24035/ijit.13.2018.003 
religion, this state can never deny the fact that Islam has come since thousand years ago. The Islamic values and cultures existed for a very long time in the community. As a medium of information channel, these two components have to be existed in the museums exhibition and activities.

Hence, the purpose of this study is to identify method used by the museums in order to expose the visitors anything related to Islam. This is really important to know because most of the tourist enter the museums just to seek for the interesting part of the exhibitions, take photos and then visit another museums without reading the write-up of the exhibitions. Other than that, researcher also wants to identify museums strategies in sustaining Islamic values and cultures in the middle of global developments besides studying the tourist awareness towards Islamic values and cultures that museums try to deliver.

Indeed, this study is also to seek for more information about Islam and tourism or tourism and its relation to Islam as a preparation of a theses entitled: Influence of Tourism towards Islamic Values in Langkawi. Melaka has been chosen because this state has been well-known as the most historical places in Malaysia. There are a lot of historical buildings remain as it is since it was built during the colonization era. There are renovations and upgrade here and there to the building but, the original shape, colors and design never been changed, only the interior changed in order to provide a conducive and comfortable environment for the visitors.

\section{Methodology}

Method used for this study is a qualitative method. The researcher first make an observation of visitors and their reaction before and after visiting the selected museums and held several interviews with informants of both sides (person in-charge of the museums and tourist/museum visitor). Some other information gathered from other articles, official websites and other sources.

\section{Objectives}

1. To identify method used by the museums organizer in order to expose the information of Islam for the visitors.

2. To identify museums organizer strategies in sustaining Islamic values and cultures.

3. To study tourists/visitors awareness towards the values and cultures of Islam that have been shown by the museums organizer.

\section{Problem Statements}

Since 2001 after the incident of 9/11, the pattern of tourism industry in the world wide have been changed. This tragedy has arouse negative stereotype towards Muslims and Islamic countries. Most of the non-Muslims especially who are not exposed directly to the Muslims cultures and their ignorance of the true colors of Islam have held campaigns to voice out their opinions that every Muslim is a terrorist. This then becoming a polemic to the global and yet spreading the notion of Islamophobic worldwide. According to Norlida et al. (2010), the free flow of the tourist destinations was to some extent has been restricted due to the safety and security reasons. For the same reasons, some major tourist destinations have imposed more restrictions and stringent regulations to the inbound tourist. This make Muslims tourist especially from the Middle East countries really careful while choosing their holiday location. 
Even though Malaysia is not part of the Middle East area, as a country with a large number of Muslims and granted Islam as a formal religion, this issue has been taken seriously. It is important to give an explanation for the community about the true colors of Islam and its beauty. The government of Malaysia lately has attempted to implement Islamic values and its cultures in tourism industries. There are a lot of ISOs filed for several fields in this industry since 2013. It can be checked from official website of Department of Standards Malaysia at www.jsm.gov.my (2017). These ISOs and standards are for tourism industry in various fields such as hotels, facilities, hospitality, restaurants and many more. At the end of the day, this effort will make tourism activities in tourism industry in Malaysia as a Muslim-friendly tourism destination.

There are numbers of museums in Malaysia. However, the number of Islamic concept of museums are less than other type of museums. One of the Islamic museums that have frequently receiving visitor locally and from the foreign tourist is Islamic Arts Museum Malaysia. It is located in the heart of Kuala Lumpur's tourist belt and amid the leafy surroundings of central Kuala Lumpur's Lake Garden (International Arts of Museum Malaysia 2017). It is built as reflect to the enormous growth of interest in Islamic art awareness and Malaysia became home to the Southeast Asia's largest museum of Islamic arts. Meanwhile, in Melaka, there is two museums with Islamic educational concept which is Quranic Museum and Islamic Museum which both organized by PERZIM (Perbadanan Muzium Melaka 2017).

The researcher arouse with the curiosity about the awareness of the tourist who visited the museums towards the values and cultures that have been trying to be exposed to the visitors. Besides, there must be strategies used by the museums organizer to deliver messages about Islam clearly to its visitors. Most of the Muslims visit the museums with Islamic educational concept does not aware on this.

Thus, this study trying to unravel these problems by using the objectives mentioned above and several interviews with informants from both sides (visitors/tourists and person in-charge of the museums).

\section{Limitation}

This study limited in Central Melaka in the state of Melaka. Only five museums selected for this study and all of them are organized by PERZIM. This is due to the role of PERZIM as the main body in the effort of gathering information, maintaining the condition of artefacts and information channel in Melaka. The five museums selected were due to its possibility and relation towards Islamic existence in the flow of history of Melaka. The five museums are Muzium Islam (Islamic Museum), Kompleks Muzium Stadhuys (Stadhuy's Complex Museum), Muzium Rakyat (People's Museum), Muzium Dunia Melayu Dunia Islam (Malay World Islamic World Museum), and Muzium Istana Kesultanan Melaka (Melaka Sultanate Palace Museum).

\section{Islam and Tourism}

Religion is an important thing for all human beings. It is caused by the human nature in needing the help of the most powerful spirit that can lead to the better future and a good life. Some people may deny that they need a god to live in this beautiful world, however, they are praying for help or at least questioning where is the help of God. This proved that every single human being needs God and to worship God we need a religion to embrace. In Malaysia, Islam has been chosen as the main religion in this country. In a book titled Change and The Muslim World (Stoddard et al.1981) said that Islam is at once a religion and a total way of life and almost a fifth of the world's people are 
Muslims, embracing this faith preached by the Prophet Muhammad PBUH (Peace Be Upon Him) over fourteen centuries ago. Among Malaysian citizens, there are people who embrace Christian, Hindu, Buddha, Tao, Sikh and etc.

Religion has played an important role for the development of many activity fields and also for human developments. According to Mehdi, Khalil \& Hassan (2012), many researches deal with religious phenomenon and analyze it as a determinant factor, a cultural element, and also an important component of economic and social activities. In many Muslims nations, Islam is found as the foundation of society and order of Islamic law principles which support tourism policy, development objectives and management. This is based on the verses in the Qur'an encouraging its believer to travel around the world for some reasons beneficial for them as a religious person as Allah the Almighty said:

Have they not journeyed in the land that their hearts might understand and their ears might listen? For indeed it is not the eyes that are blinded; it is rather the hearts in the breasts that are rendered blind (Al-Hajj 22: 46).

Say, 'Go about journeying the earth, and behold the end of those who gave the lie (to the truth)'. (al-An'am 6:11).

And publicly proclaim pilgrimage for all mankind so that they come to you on foot and mounted on lean camels from every distant point. To witness the benefits in store for them, and pronounce the name of Allah during the appointed days over the cattle hat He has provided them. So eat of it and feed the distressed and the needy (al-Hajj 22:27-28).

Based on these verses from the Quran clearly show that Islam never forbid the believers to go for travelling and journeying otherwise it encouraging the believers to tour for reasons. According to the verses, Allah the Almighty commands the believers to travel around the earth and journeying to see by themselves what has been the end of the evil doers. Not only that, Allah also commands all believers to tour for worshiping Him by witnessing the benefits in store for them and pronounce the name of Allah during the appointed days over the cattle that He has provided, eat it and feed the distressed and the needy.

In field of tourism, the commandment for touring around the world is really suitable for this purpose. Museums is the best channel to gather information about history of a place. It provide the best way of information which is presented with artefacts, arrangements of dioramas and other things related to the history. This will give a different experience in study about history and will lead it easier to understand rather than by reading historical books only, just like the common way of studying history in schools in Malaysia. Besides, write-ups placed along with the exhibitions are simple in style, concise and compact make it interesting to read and visitors will not spend so much time in the museum to understand a history.

In 2008, Islamic tourism as mentioned by Zairin (2013) was introduced in Malaysia in line with the slogan of Islam Hadhari by Tun Abdullah Ahmad Badawi, the Prime Minister of Malaysia at the time. Islamic Tourism has long been developing in the world, but still introduced in Malaysia. Malaysia is also known as a country that provides a friendly Muslim and occupied the first place with a grade of 8.3 in a Muslim-friendly holiday destination address other Muslim countries such as; Egypt, UAE, Turkey, and Saudi Arabia. The establishment of Islamic Tourism Center in early 2010 under the Ministry of Tourism Malaysia is the best platform to strengthen the tourism sector 
of the country. Malaysia is a developing country which is the focus of Muslim travelers from around the world and is known as a popular holiday destination because of its image as an Islamic country, safe and thriving. For example, during the month of Ramadhan, Muslims community in Malaysia will live up the spirit of Ramadhan by worshiping Allah as ordered in the Qur'an. Just like other Muslims' countries, Muslims in Malaysia will gather at nearby mosque to perform taraweh prayer and there are a lot of Baazar Ramadhan operating from $3 \mathrm{pm}$ to $7 \mathrm{pm}$ where all people, Muslims and non-Muslims can get different kind of Malaysian food or it can be called as 'food heaven'. One more thing, Malaysia is the Muslim-friendly holiday destination because Muslim tourists in Malaysia can easily find prayer room and worshiping Allah without any difficulties and disturbances.

These are some values and cultures of Muslims in Malaysia that can be seen by all tourist immediately once they come to visit this country. Thus, there must be a place that the visitors can come and gain some knowledge about them (reasons of Muslims doing what the visitors have seen by through their visits/ Islamic cultures and values) and the complete explanation about laws in Islam which is called sharia, pillars of Islam and many more about Islam has been placed in the museums. Besides, mosque tour activities which are more to informal educational way practiced in several mosques in Malaysia, museums are also one of the platform or information channel for local tourist, local community and foreign tourist to get to know more about Islam and it is an effort to show the true colors and the beauty of Islam itself. This will be giving the opportunity to those who want to know about this religion but do not know how to ask and who should they ask to clear up their curiosity trapped in their mind.

\section{Statistic of Museums Visitors}

From official PERZIM website shows a pattern number of visitor at its museums. It has shown as follows:

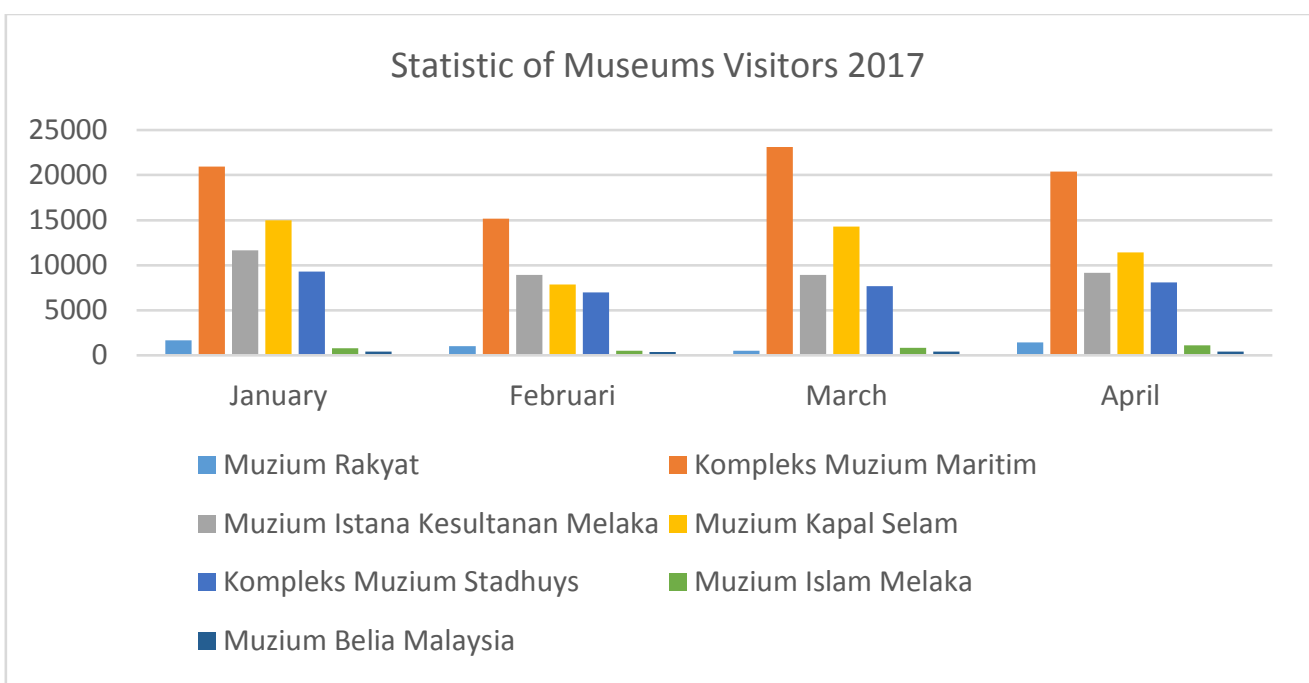

(Source: Perbadanan Muzium Melaka 2017)

Based on the graph above, it shows that the number of visitors of Islamic Museum is one of the second lowest visitors among the 4 months. From January to April, visitors of Islamic Museum are 776, 523, 843 and 1127. While the highest visitors in the record is Maritime Museum Complex which was received 20962, 15159, 23132, 20404 each month. Meanwhile, the second lowest was the Muzium Belia Malaysia (Malaysia Youth Museum) that has received 417 visitors in January, 388 
visitors in February, 395 visitors in March and 394 visitors in April. The Muzium Kapal Selam (Submarine Museum) shows unstable pattern of visitors among the 4 months. In January it received 14999 visitors in January. While, in February, the number of visitors were slightly decreased 7862 visitors and increased in March with record of 14300. The number of visitors of this museum is then decreased once again to 11421 in April. Same goes to the Muzium Istana Kesultanan Melaka (Melaka Sultanate Museum). In January the number of visitors recorded was 11635 visitors but then decreased to 8940 visitors in the month of February and 8926 visitors in March. It then increased once again in April with record of 9160 visitors. The Muzium Rakyat (People's Museum) shows the same pattern too. In January, this museum received 1672 visitors but in February, the number of visitors decreased to 994 but then increased to 1488 visitors in March. It then decreased again in April with number recorded 1440 of visitors. The Kompleks Muzium Stadhuys (Stadhuys Complex Museum) also in the top four highest number of visitors in this record. 9309 visitors have received in January but the number of visitors decreased to 6995 in February. It then increased to 7661 visitors in March and continue to increase in April with recorded number of 8089 visitors.

This clearly shows that tourist visits more to the non-Islamic museums concept than the Islamic museums. It is according to the highest number of visitors in the mentioned museums in the graph above. From seven museums listed, Islamic Museum at the bottom two. This might be due to the location of the museum or the attraction of the other museums than Islamic Museum.

Below is the graph of visitors of museums under PERZIM's organization by year:

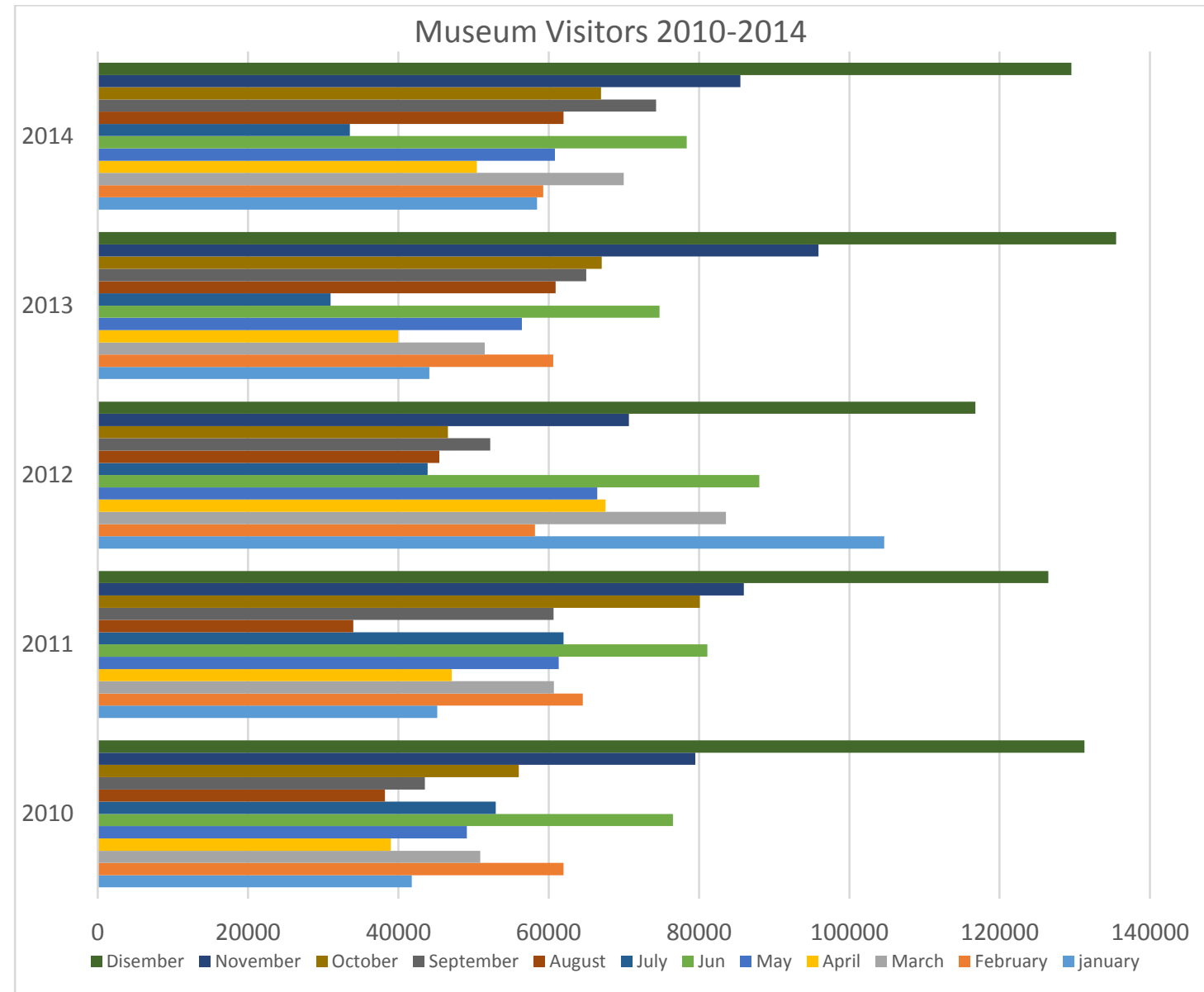

(Source: Perbadanan Muzium Melaka 2017) 
According to the graph it clearly shows that the number of visitors are incredibly high by the end of each year. At the middle of the year also shows quite high number of visitors. This might be due to the school holidays and holiday seasons. The number of visitors at the end of each year are recorded not less than 30,000 visitors.

The lowest number of visitors were in July 2013 which recorded 30,961 visitors compared to the number of visitors in 2010, 2011, 2012 and 2014 which recorded 52,953, 61,953, 43,881 and 33,526 visitors each. Meanwhile in December, the lowest number of visitors was on December 2012 with record 116, 794 compared to the number of visitors recorded in 2010, 2011, 2013 and 2014. The highest number of visitors among these years recorded on the graph was on December 2013 which was recorded 135,492 visitors. In the previous year which is 2012 in the month of January, the number of visitors recorded the highest compared to the number of visitors in the same month of 2010, 2011, 2013 and 2014. It was recorded 104,641 visitors compared to the other years in same month was not exceed than 59,000 visitors.

Based on researcher's observation, at the middle of the year, there are numbers of buses with groups of foreign tourist occupying Central Melaka area especially at Banda Hilir. It has been agreed by the museums employee. They claimed that tourists from China will visit Melaka every year and recently the number of tourists from Japan and Korea are increasing. Their visit might be due to the summer vacation at their country that gives them the good opportunity to visit other country like Malaysia. Besides, during this times, it is less rainy days and will open the opportunity for them to enjoy their visit without interruption of natural phenomena. This weather also make the views clear and provide the best scenery for the tourist to enjoy their times here. Meanwhile, the highest number of museums visitors is in month of December each year. In Malaysia, the longest period of school holiday is in the end of November until the end of December or early January. During this period, there are a lot of school trips and other programs that will educate the participants about history of this country. There are a lot of activities outside the museums that will add more fun and the best experience of the tourist such as tricycle and horseback riding.

\section{Results and Discussions}

Based on the observation and information gathered from various sources, the researcher finally came to a result as the following:

\section{Method used by museums organizer in order to expose Islam to the visitors}

According to Sabri (2017), an informant who is one of the person in-charge in Melaka Sultanate Palace Museum, there are a lot of Islamic values in cultures in museums' dioramas, miniatures and write-ups. By focusing on Melaka Sultanate Palace Museum, there are Islamic values shown in the diorama of trader giving ufti (gift) to Sultan of Melaka. There are also have a lot of traditional Malay clothes by from each state in Malay Land which have the combination of Malay traditional elements and Islamic elements. He said that the value of Islam and its cultures can only be seen by those who are really aware about the values behind every single part of the exhibitions in the museum. This is due to the role of palace before the colonization which has been a place of teaching Islam by the Arabic traders.

Nor Aliya (2017) (informant: person in-charge in People's Museum) said that at People's Museum is hard to find the values of Islam neither its cultures. This is because this museum only have the exhibitions about the community in Malay Land until now it is known as Malaysia. It has explanations on how the other races came to this land and became local community, their cultures, 
their clothes and the traditional games played by old community in the history. Some of them are well known by the latest generation which is known as Gen Y and Gen Z but most of them are rarely heard and not even played these days.

From the observation held to the all five museums, most of them are focusing on historical values where the Malay cultures have been clearly shown in the exhibitions. Only in the Malay World museum, Islamic World Museum and Islamic Museum have a clear Islamic values and its cultures. Visitors can read from the write-up provided below the diorama and artefacts. In these two museums also have replicas of Islamic things such as; the old versions of the Holy Quran, original shape/design of old mosques, potteries, swords, clothes used by pondok students in the history and etc.

\section{Museums Organizer Strategies in Sustaining Islamic Values and Cultures}

PERZIM has its own strategies or method in order to sustain the Islamic values and cultures in Melaka. Based on the observation, the effort is included or it can be called as hiding behind the other elements of historical exhibitions in the museums other than Islamic Museum. This is according to the words of Mr. Sabri written above, the values of Islam can be seen through the dioramas arranged in the museums which mean the clothes on the mannequins, its arrangements and more. If visitors are aware about this, they will clearly see the values of Islam implemented during Melaka Sultanate era. While those who are not really concern will only see the Malay cultures and the situations during Melaka Sultanate era before the colonization by the Europeans armies.

Malay World Islamic World Museum and Islamic Museum are two museums providing a clear evidence of the existence of Islam in Malay Land in recorded history and its growth until today. PERZIM is really keen to seek for the artifacts and books related to the history of Islam from various sources including exhibitions held by Islamic Arts Museums in Kuala Lumpur and other organizations. Until today, these two museums have been occupied by artifacts and replicas such as; potteries, old versions of the holy Quran, swords and many more as mentioned before. There are also activities held to expose to the public including the tourist about the exhibitions in the museums. Besides, the promotion team will go around Malaysia from state to state and also international to promote the uniqueness of Melaka and activities held by the museums organizer. This may literally looks like only a promotional strategy but in my opinion, it is also the strategies of the museums organizer to bring community closer to the museums and history besides this is the effort on sustaining values of Islam and also the effort for the community to not forgetting history. Because history is not only has to be written in books and exhibit at the museums but it has to be learnt in order to build a better future.

\section{The Awareness of Visitors Towards the Values and Cultures of Islam Showed by the Museums Organizer}

According to Abdul Jalil (2017) (informant: person in-charge in Malay World Islamic World Museum), visitors of the Malay World Islamic World Museum are not really aware about this. Most of them visiting the museum to seek for the interesting parts in the museum, taking pictures and then visit the other museums. Same goes to the youngsters aged 15-17 who comes for gathering information to complete their school tasks. They do the same things as the other visitors without interviewing the person in-charge of the museum or asking one or two questions to other visitors. 
Abdul Jalil said that this action will lead to the nothingness of the visits and Muslims will never be a good Muslim without appreciation of the history of their own religion.

Rahim (2017) (informant: person in-charge in Islamic Museum) said that Islamic Museum received lesser visitor compared to the other museums. This approved by the graph at the previous section of this paper. According to him, most of the tourist only visit the outer part of the museum because at the front of the museum has replica of the old tombs from the early time of the coming of Islam to the Malay Land, prayer times tools, murals and mimbar. They will immediately exit the museum when they see the ticket counter. It is maybe due to the building conditions which is too old make it looks unattractive for the tourist/visitors.

Muhammad Azmer Azmi (2017) (visitor/local tourist) said that most of the museums only provide the information about the history of Malay Land and after the Independence Day. It is hard to find values of Islam clearly from the museums except Malay World Islamic World Museum and Islamic Museum. When he was asked to rate the values of Islam and its cultures based on his experiences or observations to the museums he has visited, he rated $80 \%$ of the information from the museums are not related to the Islam, neither values nor its cultures.

Ong from Penang (2017) (visitor/local tourist) said Melaka has its own uniqueness that can never be seen or get from other places. She said this is the best place to visit and bring children for holiday due to the sustained historical elements and heritages. It will open the opportunity for the children as well as the adults/parents to learn about history of their own country by looking or visiting the place by their own eyes and experiencing being in the historical building by themselves. When she was asked about the values and cultures of Islam that she can observe or get from her visits, she said it can be seen everywhere and this kind of things added more colors of tourism activities in Melaka.

With the comparison of these two visitors' opinions, it have approved the words of Mr. Sabri that have mentioned about only those who are really concern will aware about the Islamic values and cultures hiding behind each of the exhibitions in the museums. Indeed, Ong also said the same things at the end of the interview. She said "you are born as a Muslim and you are used to this places because you are raised here. You can never aware about this unless you go to other places and observe the difference."

From all of the information gathered, the researcher has finally comes to a conclusion. The researcher concluded that each museum has its own ways in expressing the values and cultures of Islam. The most important thing is visitors own awareness about the values hiding behind each of the elements and information provided by the museum organizer. In fact, the Museum organizer has done a great work in gathering, maintaining and providing information for the community and tourists.

\section{Acknowledgement}

This research was financially supported by the Topdown Research Grant Scheme from the National University of Malaysia, UKM Bangi, Selangor. [Grant No.: TD-2016-001].

\section{References}

Al-Quran Al-Karim Al-Mubarak with English Translation and Guide on Waqaf and Ibtida'. Kuala Lumpur: Telaga Biru Publication.

Abdul Jalil Baharem. Interview. June, 2017.

https://doi.org/10.24035/ijit.13.2018.003 
Andek Masnah Andek Kelawa. 2010. Pelancongan Menurut Perspektif Islam: Galakan dan Harapan. In. Abdul Ghafar Don \& Razaleigh Muhamat @ Kawangit. Islam dan Pelancongan:Isu dan Cabaran. Bangi: FPI UKM.

Departments of Standards Malaysia. 2017. The Official Websites of Departments of Standards Malaysia. Online. www.jsm.gov.my. 23 August 2017.

Hamzah Jusoh, Habibah Ahmad, Amriah Buang, Ari Kurnia. 2011. Melaka sebagai Pintu Masuk Pelancongan Sumatera: Perkembangan Semasa dan Cabaran Global. Malaysian Journal of Society and Space. 7 (Special issue): 2-13.

Islamic Arts Museum Malaysia. 2017. Online. www.iamm.org.my/about-us. 23 August 2017.

Mehdi Pourtaheri, Khalil Rahmani \& Hassan Ahmadi. 2012. Impact of religious tourism and pilgrimage tourism in rural areas: the case of Iran. Journal of Geography and Geology. 4 (3): 33-45.

Muhammad Azmer Azmi. Interview. June 2017.

Nor Aliya Abdul Ghani. Interview. June 2017

Norlida Hanim Mohd Salleh, Abu Hasan Shaari Mohd Noor, Mohd Safar Hasim \& Redzuan Othman. 2010. Permintaan Pelancongan Malaysia dari Pasaran Timur Tengah: Suatu Kajian Awal. International Journal of West Asian Studies. 1: 37-52.

Ong, Jenifer. Interview. June 2017.

Perbadanan Muzium Melaka. 2017. Background of PERZIM. Online. www.perzim.gov.my/ms/perzim/ info-perzim/background-of -perzim/. 5 Sept 2017.

Perbadanan Muzium Melaka. 2017. Fungsi, Visi dan Misi PERZIM. Online. www.perzim.gov.my/ms/ perzim/info-perzim/fungsi-visi-misi. 5 Sept. 2017.

Perbadanan Muzium Melaka. 2017. Statistik Pelawat Muzium. Online. www.perzim.gov.my/ms/perzim/ statistik-pelawat-muzium/. 17 Sept 2017.

Rahim Jaafar. Interview. June 2017.

Ruziah Ali, Fatonah Salehuddin, Rahizah Abd Rahman, Faradila Md Yusof, Mohd Hafizuddin Yusof \& Yang Chik Abdul Rahman. 2014. Melaka Wadah Tumpuan. Melaka: UTEM.

Sabri Aikerkek. Interview. June 2017.

Stoddard, H. et.al. 1981. Change and the Muslim World. Washington; Syracuse University Press.

Zairin Akma Zolkapli, Chamhuri Siwar, Habibah Ahmad \& Hamzah Jusoh. 2013. Taman Tamadun Islam Sebagai Produk Pelancongan Islam: Persepsi, Kepuasan dan Jangkaan Pelancong. Prosiding Perkem Viii. Vol. 1: 179 - 190. 